This item was submitted to Loughborough's Research Repository by the author.

Items in Figshare are protected by copyright, with all rights reserved, unless otherwise indicated.

\title{
An examination of cross-border strategies in banking
}

PLEASE CITE THE PUBLISHED VERSION

http://dx.doi.org/10.1080/02642069.2010.504815

PUBLISHER

(c) Taylor and Francis

VERSION

AM (Accepted Manuscript)

LICENCE

CC BY-NC-ND 4.0

REPOSITORY RECORD

Howcroft, Barry, Rehan ul-Haq, and Chris Carr. 2019. "An Examination of Cross-border Strategies in Banking". figshare. https://hdl.handle.net/2134/14627. 
This item was submitted to Loughborough's Institutional Repository (https://dspace.lboro.ac.uk/) by the author and is made available under the following Creative Commons Licence conditions.

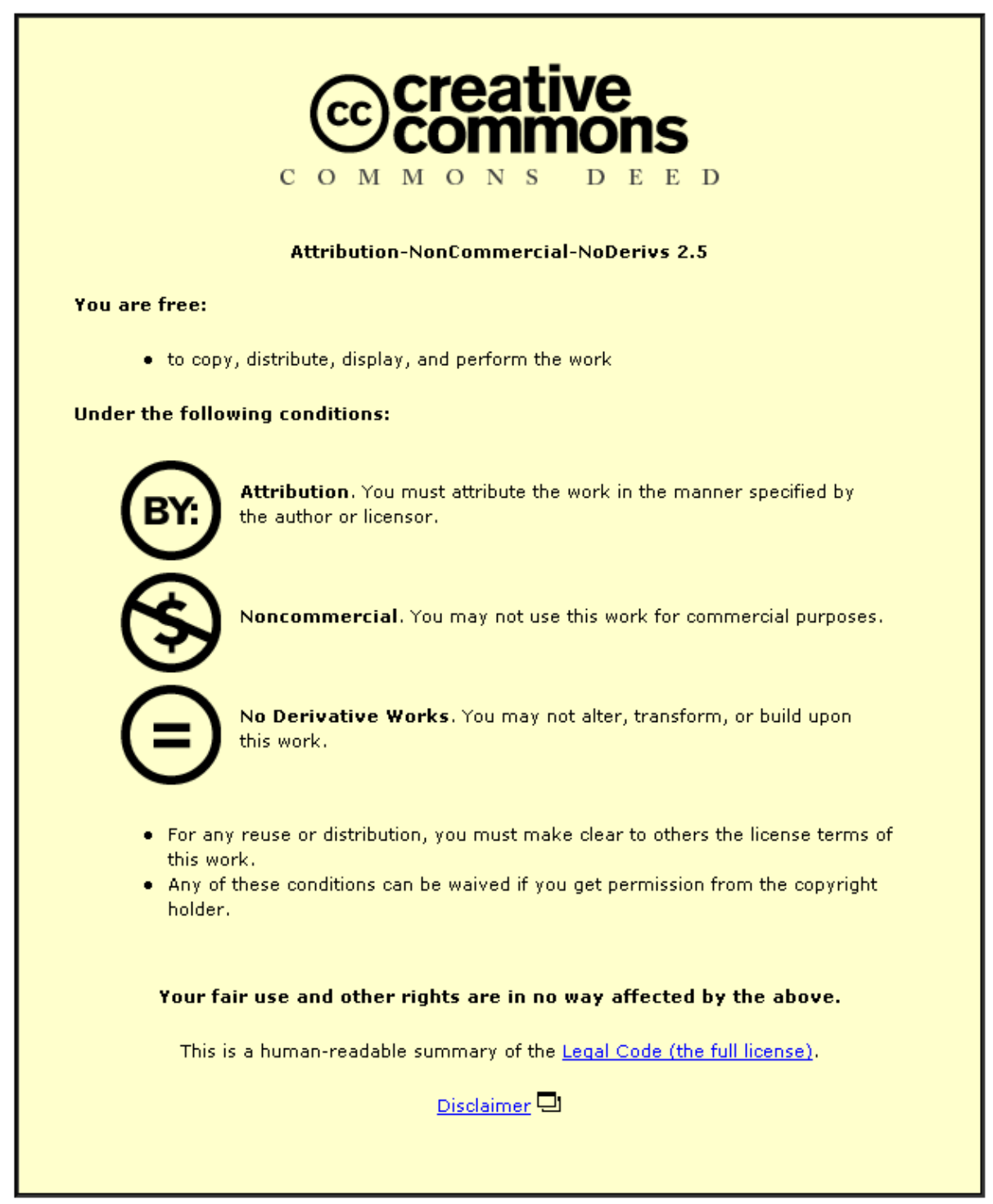

For the full text of this licence, please go to: http://creativecommons.org/licenses/by-nc-nd/2.5/ 


\title{
An examination of cross-border strategies in banking
}

\author{
John Barry Howcroft ${ }^{\mathrm{a} *}$, Rehan ul-Haq ${ }^{\mathrm{b}}$ and Chris Carr $^{\mathrm{c}}$ \\ ${ }^{a}$ Business School, Loughborough University, Loughborough LE11 2TU, UK; ${ }^{b}$ Birmingham Business \\ School, University of Birmingham, University House, Edgbaston, Birmingham B15 2TT, UK; \\ 'School of Business and Economics, University of Edinburgh, 50 George Square, Edinburgh EH8 \\ 9JY, UK
}

\begin{abstract}
The paper examines the process of bank internationalisation and explores how banks become international organisations and what this involves. It also makes an assessment of the significance of their international operations and determines whether banks are truly global organisations. The empirical data are based on the 60 largest banks in the world and content analysis is used to categorise the information into the eight international strategies of Atamer, Calori, Gustavsson, and Menguzzato-Boulard [Internationalisation strategies. In R. Calori, T. Atamer, \& P. Nunes (Eds.), The dynamics of international competition - from practice to theory, strategy series (pp. 162-206). London: Sage (2000)] and Bryan, Fraser, Oppenheim, and Rall [Race for the World strategies to build a great global firm. Boston, MA: Harvard Business School Press (1999)]. The findings suggest that the majority of banks focus on countries or geographic regions in which they have some sort of cultural or economic affinity. Moreover, apart from a relatively small number of very large banks, they are international rather than truly global organisations.
\end{abstract}

Keywords: cross-border strategies; banking; globalisation; internationalisation

\section{Introduction}

The emergence of countries such as China and India and the general trend towards economic opening has led to announcements of global strategic intent by virtually all of the major companies in recent years (Grosse, 2005). However, a primary consideration in focusing specifically on the cross-border activities of banks emanated from the sheer size of their international activities. For example, a cursory examination of foreign assets as a percentage of total assets of the 30 largest banks reveals that they increased from 35\% in 1980 to over 38\% by 2003 (De Nicolo, Bartholomew, Zaman, \& Zephirin, 2004). Moreover, the absolute size of the foreign assets of these same banks increased 11-fold from $\$ 650$ billion in 1990 to over $\$ 7571$ billion in 2000 (Slager, 2005). Prior to the credit crunch, the global banking sector was estimated to have had a market value in excess of $\$ 65,700$ billion in 2005 (Datamonitor, 2006).

This unparalleled growth in the international activities of banks can be traced back to a range of environmental and regulatory changes (Focarelli \& Pozzolo, 2001). Inter alia these include restrictive regulatory and monetary policies in the USA, which effectively forced American banks to establish off shore centres in Europe and elsewhere (ul-Haq \& Howcroft, 2007). Deregulatory measures that created level playing fields also resulted in a fundamental shift in the nature of competition in financial markets (Slager, 2005). As a 
consequence, banks began to adopt 'market-seeker' strategies and expand their crossborder activities (Alavarez-Gil, Cardone-Riportella, Lado-Couste, \& Samartin-Saenz, 2003; Roberts \& Arnander, 2001). Unprecedented developments in communication infrastructures, particularly those dependent on information technology and the internet also provided an unprecedented opportunity for banks to become international (Grosse, 2004).

More recently, the banking crisis has caused unprecedented environmental and regulatory changes that have fundamentally altered the competitive structure of financial markets. As a consequence, the crisis has forced banks to reassess their core competences and implement strategies that are conducive to sustainable competitive advantage. Such strategies, irrespective of whether they are based on retrenchment or expansion, typically focus on considerations relating to customer service, state of the art technology, the composition of the service portfolio, etc. (Gardener, Howcroft, \& Williams, 1999). In this respect and somewhat crucially from the perspective of this paper, the process of internationalisation is yet another strategic imperative that is conducive to maintaining competitive advantage.

In terms of size, management culture, operational markets, etc., individual banks can be quite different and this raises the possibility that the process of internationalisation, i.e. how firms become international, and even the meaning of the term international, might not be the same for all banks. Accordingly, the study addresses the following research questions: to what extent are general patterns of bank internationalisation discernable and what factors influence and determine the process of internationalisation. The paper, therefore, ascertains how individual banks become international and what this involves. In addition, it also makes an assessment of the significance of the international activities of banks and determines whether they are truly global organisations.

These are important considerations because despite the size and growth of international banking, there is a dearth of academic research on the range of cross-border strategies available to banks. In addressing this deficit in the extant literature, the paper, therefore, draws upon the more general literature on the internationalisation of the firm. To facilitate these objectives, content analysis is used to identify predetermined themes and patterns form the annual reports of the world's largest 60 banks. Theses themes are then applied to the Bryan, Fraser, Oppenheim, and Rall (1999) and Atamer, Calori, Gustavsson, and Menguzzato-Boulard (2000) typologies for classifying international strategies.

The paper is organised as follows: the next section comprises the literature review, which commences with an examination of the relevant literature on internationalisation. The research model and research methodology are then discussed together with the bank sample. The data are then presented and the findings analysed within the context of the research model. Finally, the conclusion summarises the main findings, makes an assessment of the managerial implications, identifies some of the limitations of the paper and discusses how future research in this area can be developed.

\section{Literature review}

Although by no means exhaustive, the following examples are illustrative of the broad range of considerations emphasised in the literature on international banking: crossborder bank mergers and acquisitions (Buch \& De Long, 2004; Vander Vennet, 1996); the relationship between globalisation and bank efficiency (Amel, Barnes, Pannetta, \& Salleo, 2003; Berger, DeYoung, \& Udell, 2001); the strategic response to globalisation (Karimi, Yash, \& Somers, 1996; Slager, 2005); the Europeanisation of banks (Goddard, 
Molyneux, Wilson, \& Tavakoli, 2007; Nellis et al., 2000); foreign bank entry into developing economies (Clarke, Cull, Soledad, Peria, \& Sanchez, 2003; Dages, Goldberg, \& Kinney, 2000); horizontal and vertical integration (Buch \& Lipponer, 2007; Goddard et al., 2007; Hauswald \& Marquez, 2006; Helpman, Melitz, \& Yeaple, 2004); trends in international banking (De Nicolo et al., 2004; Focarelli \& Pozzolo, 2005); etc.

The academic literature on the internationalisation of firms can be dichotomised into two broad categories. The first category articulates the mains explanatory reasons as to why firms internationalise; and the second, which derives from the strategic management literature, develops the notion of differentiation. As such, it focuses on how firms internationalise and the different types of international strategy.

Commencing with the first of these categories, the relevant literature emanates from several distinct sources or schools of thought: the behavioural school is represented by authors such as Dunning (1997), Weiss (2005), Chang (2004) and Sapienza, Autio, Geage, and Zahara (2006), etc., who have emphasised the importance of regulatory push and how regulations aimed at protecting domestic firms can constrain domestic competition and cause firms to seek more profitable opportunities in less regulated foreign markets.

Regulatory push is an important consideration for banks (see, e.g. Alavarez-Gil et al., 2003; Focarelli \& Pozzolo, 2001; Roberts \& Arnander, 2001; Slager, 2005, etc.). However, the literature also recognises that there are substantial barriers to internationalisation. Inter alia these barriers include differences in national economies, culture, language, fiscal and legal systems (Berger et al., 2001; Berger, Dai, Ongena, \& Smith, 2003; Buch \& Heinrich, 2002; Lewis, 2003). Moreover, these barriers are, especially, prevalent in commercial banking where access to information, trust and familiarity, i.e. factors that are crucial in the formation of banking relationships, are important considerations (Barros et al., 2005; Beitel \& Schiereck, 2001; Kwok \& Tadesse, 2006).

Rugman and Verbeke (1998), Buckley and Casson (1998), Alavarez-Gil et al. (2003), Westney (2006), Friedman (2007), etc., fit comfortably within the behavioural school but they take a different perspective on internationalisation. They explain it in terms of market pull or market-seeker strategies and the need to pursue profitable opportunities in foreign markets or centres of excellence. This body of literature argues that firms are primarily motivated by self-interest and undertake strategic interactions with their external environment (see, e.g. ul-Haq \& Howcroft, 2007; Lawson, 1997). They also emphasise the importance of senior management and how managerial decisions are determined by internal considerations relating to corporate culture, and internal administrative and managerial competences (Ramachandran, Mukherji, \& Sud, 2006; Yang, Leone, \& Alden, 1992). In this respect, Sapienza et al. (2006) has found evidence to show that banks have a tendency to locate in financial centres in order to be at the cutting edge of financial innovation. This approach also facilitates the acquisition of additional resources in the form of propriety knowledge and skills, which can be transferred elsewhere within the organisation.

Johanson and Vahlne's (1977) seminal paper focuses on the incremental nature of internationalisation and similarly comes within the behavioural school of internationalisation. Their so-called Uppsala international model places emphasis on the gradual acquisition, integration and use of knowledge about foreign markets. The model is also predicated on the basic assumption that a lack of such information is a major barrier to the process of internationalisation. Moreover, advocates of this approach (Denrell, Fang, \& Winther, 2003; Erramilli, 1991; Luo, 1999) emphasise that such knowledge 
can best be acquired through foreign operations and that it incrementally informs future internationalisation decisions.

Closely aligned to this approach is Caves (1982) process theory and writers such as Anderson (1993), Westney (2006), Ramachandran et al. (2006), etc., argue that internationalisation is an evolutionary process, which takes place by incremental steps. Central to an understanding of this approach is the concept of 'psychic distance' and the notion that firms expand to neighbouring countries that have social, political and economic similarities with the home country. Risks associated with internationalisation increase proportionately with dissimilarities between the home and host country and, therefore, the theory argues that firms tend to adopt either an exclusively domestic policy or a regional focus. However, unprecedented levels of innovation and deregulation, particularly in financial services, have arguably reduced these geographic and spatial barriers (see, e.g. Berger et al., 2001). In contrast, however, authors such as Barros et al. (2005) have argued that there are still significant barriers to cross-border strategies.

The literature also discusses internationalisation in terms of diversification (Bauer, 1994). Accordingly, Berger et al. (2003), Altman, Brady, Resti, and Sironi (2005) and Bikker and Metzemakers (2005) argue that banks diversify geographically in an endeavour to spread risk and reduce procyclical characteristics. This enables them to potentially reduce the effects of domestic recession. However, in instances where there is a global recession or where an industrial sector, such as banking, is susceptible to systemic risk, international diversification may provide less protection.

The profit motive is another powerful consideration in explaining internationalisation. This partially explains why there is a direct relationship between bank size, size of the home country banking sector and global spread (see, e.g. Grosse \& Goldberg, 1991; Tschoegl, 1983; Williams, 1998). To the extent that maximising profits is an important imperative behind internationalisation, selecting the right host country or region is a critical part of an international strategy. Accordingly, Focarelli and Pozzolo (2001) found that foreign banks were attracted to countries with high levels of economic growth. Similarly, Claessens, Demirguc-Kunt, and Huizinga (2000) found that foreign banks were attracted to host countries with relatively low taxation regimes and high per capita income.

In contrast to the behavioural school, the second broad category of internationalisation derives from the economic theory of internationalisation and fits within the general or eclectic ownership, location and internationalisation (OLI) paradigm (see, e.g. Dunning, 2001). Somewhat crucially, for the purpose of this paper, it provides some insight into the different types of international strategy. In particular, it suggests that differentiation stems from the unique combinations of resources at the firm level. To the extent, therefore, that banks are characterised by heterogeneous supply chains and a diverse range of customer needs, ceteris paribus one would anticipate that there will be considerable variation in their international strategies.

Competitive behaviour and, therefore, variations in international strategies are also determined by the cognitive perceptions of senior management. To some extent, these perceptions are determined by the resources and core competences of the firm. However, management perceptions are also influenced by other considerations, such as the firms history, its idiosyncratic administrative abilities, the home country's business culture and the structural characteristics of the domestic markets (Lumpkin \& Dess, 1996; Ramachandran et al., 2006; Rugman \& Verbeke, 1998).

With a few exceptions, the seminal work on analysing different strategic configurations dates back to the 1980s and relies on contingency theory (Lawrence \& Lorsch, 1967), population ecology (Hannan \& Freeman, 1984) and institutional theory 
(Di Maggio \& Powell, 1983). These theories suggest that there are a limited number of viable strategies, which are largely determined by the environmental context and replicated by competitor firms.

Fayerweather (1969) and Doz (1980) identified two important dimensions of differentiation: geographic scope and standardisation. Geographic scope can be either broad or narrow and was defined as the set of targeted key countries. Standardisation, as opposed to the opposite dimension, fragmentation or local responsiveness, was defined as the homogeneity of the firm's competitive approaches in different countries. Subsequently, authors such as Bartlett and Ghoshal (1989), Doz (1996), etc., introduced a complementary dimension, which they referred to as the level of integration or co-ordination of activities across borders. Kogut (1985a, 1985b) and Porter (1986) added another dimension, which they referred to as the 'geographic configuration of value chain activities'. This dimension takes into account that firm-specific competitive advantages are related to the comparative advantages of countries. Accordingly, firms will locate various aspects of their value chain, i.e. research and development, marketing, manufacturing, etc., in an endeavour to exploit location-specific advantages. A fifth dimension known as 'segment scope' was introduced by Porter (1986) to take into account the fact that firms can internationalise using either a narrow or a broad product range.

What was interesting about Porter's (1986) work was that he attempted to ascertain the answer to two related questions, namely what the composition of an international strategy is and how it is achieved. Accordingly, he used geographic and segment scope to address the first question, and international configurations and international co-ordination to ascertain the latter. The main criticism of Porter's approach, however, was that it did not explicitly relate the two dimensions by incorporating them into a single typology.

\section{Research model}

In order to examine the different international strategies of the world's major banks, it was decided to use an adaptation of Atamer et al.'s (2000) typology. Atamer et al. (2000) identified eight international strategies, which were based on the five theoretical dimensions discussed above. The typology was constructed from a fairly extensive series of interviews with senior managers in four industrial sectors. Content analysis was then used to ascertain the main themes or dimensions and relate them to the different international strategies. Atamer et al. divided international strategies into two broad categories, namely firms with a worldwide geographic scope and those with a more focused geographic scope.

The first category referred to as 'worldwide players' has a significant involvement in the most important markets in the world and is characterised by high cross-border integration. Firms that adopt this approach, however, can differ quite considerably in terms of segment scope, foreign investment policy, standardisation and integration of value chain activities. Accordingly, Atamer et al. (2000) categorised them into four configurations or sub-strategies: quasi-global players, transnational restructurers, worldwide technology specialists and global luxury niche players.

Quasi-global players have a worldwide geographic scope and relatively narrow segment scope. Accordingly, they focus on one or two segments on a worldwide basis. Production is focused on a few countries and sometimes certain aspects of production and delivery are outsourced. Their international strategy is homogeneous, which means that variations in marketing are minimal, global branding is very important and they are typified by a large expenditure on advertising. Costs and efficiencies through economies of scale are controlled by focusing on a small number of brands and having a narrow 
product range. These firms are also regarded as innovators or pioneers within their sector and try to maintain differentiation through continuous improvement.

Transnational restructurers are characterised by a strong corporate image and high levels of product and service quality. They also have a worldwide geographic presence, a broad segment scope and are involved in most product-market segments. The primary objective of these firms is to achieve a worldwide leader position by growing the business via domestic and international mergers and acquisitions. This approach is conducive to expanding and acquiring new core competences but it can also lead to overly complex organisational structures with multiple locations spread throughout the world. For example, some activities in the value chain might be globally integrated whereas other activities could be organised to preserve local responsiveness. These firms also have a tendency to suffer from duplication of resources and overcapacity and, therefore, they frequently introduce rationalisation programmes to reduce costs and simplify their operations.

Worldwide technology specialists are mainly characterised by ownership of specific technological know-how and expertise that provides them with a significant worldwide competitive advantage. Their international process is predicated on the premise that they have a unique set of technical skills, which differentiate them from competitors. For the purposes of this paper, it was, therefore, decided that this configuration was not appropriate for an examination of banks. This was because banks tend to differentiate on size of the business, quality and scope of the product portfolio, quality of service, etc., rather than on the exclusive ownership of superior technological know-how.

However, it was found that Bryan et al.'s (1999) 'global shapers' could be usefully incorporated into Atamer et al.'s (2000) typology. Firms represented by this strategy have worldwide geographic coverage and typically focus on a niche or a narrow segment of a mass market. They develop the business via organic growth or franchising arrangements and place an emphasis on standardisation of products and services. Their activities are globally integrated but they are extremely adept at collating information, and making reflective and timely decisions that help to shape the future structure of the market or industry. In essence, they can be regarded as innovators and calculated risktakers who are instrumental in triggering change.

The final sub-category of worldwide players is global luxury niche players. They access world markets by differentiating themselves on the basis of top quality products and high levels of service quality. Accordingly, they normally have a strong company or brand name that is readily associated with luxury and high net worth customers. International firms in this category generally have a very narrow focus on high-priced products and typically target a specific market segment. They also have a homogeneous core product line and production is concentrated in the home country.

Atamer et al.'s (2000) second broad category of international strategies, namely international challengers is representative of a range of strategies that lie somewhere between the purely global and purely domestic extremes. As with worldwide players, it consists of four sub-strategies: continental leaders, opportunistic international challengers, which are associated with an offensive strategy, and geographic niche players and country-centred players, which are essentially defensive.

Continental leaders are characterised by their focus on a single continent and a relatively large segment scope. Firms normally concentrate on the major product-market segments within their geographic zone and they aim to achieve a high level of integration and co-ordination. The product and service range is typically standardised but products are adapted to continental specificities. The primary objective of these firms is to achieve 
sustainable competitive advantage in a relatively large geographic area. Accordingly, they place emphasis on new product development, efficiency and service quality.

Opportunistic challengers typically consist of firms that are regarded as leaders in their home country. In terms of international development they tend to focus on a few segments and take advantage of any market opportunities that come their way. Geographic scope can be large and extend beyond a single continent but the associated dispersion of international assets and sales means that they seldom achieve dominant market share in a foreign country. To some extent this is a reflection of their opportunist behaviour, which is indicative of firms that are in a transitory stage waiting for corporate plans to be properly formulated.

Geographic niche players try to defend their strong domestic position and extend it into a larger geographic zone consisting of neighbouring countries or countries with cultural, political, social and economic similarities. Geographic scope, therefore, could be determined by a trade bloc, such as the European market, the Far East or Latin America, etc., but it could equally be determined by market pull consideration and the need to follow customers into overseas markets. Firms typically have a consistent product range throughout their operational markets. They invest in subsidiary companies in an endeavour to provide a differentiated service, which is based on superior quality predicated on their responsiveness to local needs and preferences. They compete very effectively with worldwide or continental players and can capture a high market share in the competitive territory. In this respect, they represent very attractive acquisition targets, especially, for transnational restructurers and continental players.

Country-centred players represent Atamer's final category of international challengers. They are characterised by a focus on the home country and defend (or strengthen) their position against foreign competitors. Internationalisation is regarded as a marginal activity, and international competition is regarded as multidomestic. Firms, accordingly, focus on one or a few product-market segments in which local responsiveness is regarded as a major success factor. They can also evolve into the more ambitious geographic niche players but (like geographic niche players) they represent attractive acquisition targets.

Table 1 summarises and relates the eight strategic classifications to the five theoretical dimensions. However, because Atamer et al. (2000) typology was based on empirical evidence from industries other than banking, namely, footwear, cables and wires, paint, and confectionery, it was necessary to adapt the theoretical dimensions to reflect more accurately the specific characteristics of the banking industry. In essence, the banking industry, particularly, in terms of its customer base and product portfolios, is a relatively complicated and multifaceted business. This consideration also raises the distinct possibility that individual banks could be simultaneously pursuing more than one international strategy at any one time. It was, therefore, necessary to categorise strategies on what was identified as the most prominent or dominant theme.

Accordingly, the following rules of thumb were adopted in specifying the dimensions of the typology: geographic scope was based on the main countries in which each of the banks had operations and a physical presence through representative offices and subsidiaries. Segment scope was determined by the primary operational segments and breadth of the product range of each institution. Entry mode was largely determined by whether the institution had a propensity for organic growth or merger and acquisitions, and whether there was any evidence of franchising or licensing arrangements in the host countries. The standardisation dimension was based on whether there was any evidence of high levels of product standardisation and whether the product portfolio was essentially homogenous or not. Finally, international integration 
Table 1. International strategy configurations.

\begin{tabular}{|c|c|c|c|c|c|c|c|c|}
\hline & $\begin{array}{l}\text { Country- } \\
\text { centred } \\
\text { players }\end{array}$ & $\begin{array}{l}\text { Geographic } \\
\text { niche players }\end{array}$ & $\begin{array}{l}\text { Opportunistic } \\
\text { international } \\
\text { challengers }\end{array}$ & Continental leaders & $\begin{array}{l}\text { Global luxury } \\
\text { niche players }\end{array}$ & $\begin{array}{l}\text { Quasi-global } \\
\text { players }\end{array}$ & $\begin{array}{l}\text { Transnational } \\
\text { restructurers }\end{array}$ & Global shapers \\
\hline Geographic scope & $\begin{array}{l}\text { Home } \\
\text { country, gain } \\
\text { market share }\end{array}$ & $\begin{array}{l}\text { Set of countries } \\
\text { forming a } \\
\text { homogeneous } \\
\text { territory, gain } \\
\text { market share }\end{array}$ & $\begin{array}{l}\text { Home country } \\
\text { and a few key } \\
\text { countries, } \\
\text { market share or } \\
\text { market coverage }\end{array}$ & $\begin{array}{l}\text { All key countries in } \\
\text { a continent, gain } \\
\text { market share }\end{array}$ & $\begin{array}{l}\text { All key } \\
\text { countries }\end{array}$ & $\begin{array}{l}\text { All key } \\
\text { countries, } \\
\text { gain market } \\
\text { share }\end{array}$ & $\begin{array}{l}\text { All key } \\
\text { countries, wide } \\
\text { coverage and } \\
\text { market share }\end{array}$ & $\begin{array}{l}\text { All key countries, } \\
\text { wide coverage }\end{array}$ \\
\hline Segment scope & Narrow & $\begin{array}{l}\text { Relatively } \\
\text { narrow }\end{array}$ & Few segments & Relatively large & $\begin{array}{l}\text { Narrow, high- } \\
\text { priced } \\
\text { segments }\end{array}$ & $\begin{array}{l}\text { Narrow, but } \\
\text { concerns mass } \\
\text { market }\end{array}$ & $\begin{array}{l}\text { Large, most } \\
\text { business } \\
\text { segments }\end{array}$ & $\begin{array}{l}\text { Narrow, but } \\
\text { concerns mass } \\
\text { market }\end{array}$ \\
\hline $\begin{array}{l}\text { FDI policy/entry } \\
\text { mode }\end{array}$ & Variable & $\begin{array}{l}\text { Mainly organic } \\
\text { growth }\end{array}$ & Variable & $\begin{array}{l}\text { Mainly organic } \\
\text { growth }\end{array}$ & $\begin{array}{l}\text { Licensing and } \\
\text { franchising }\end{array}$ & $\begin{array}{l}\text { Mainly } \\
\text { organic } \\
\text { growth }\end{array}$ & $\begin{array}{l}\text { Most entry } \\
\text { modes, } \\
\text { frequent M\&A }\end{array}$ & $\begin{array}{l}\text { Organic or } \\
\text { franchising }\end{array}$ \\
\hline Standardisation & Homogeneous & Homogeneous & Variable & $\begin{array}{l}\text { Relatively } \\
\text { homogeneous }\end{array}$ & Homogeneous & Homogeneous & Heterogeneous & $\begin{array}{l}\text { Heavy } \\
\text { standardisation }\end{array}$ \\
\hline $\begin{array}{l}\text { International } \\
\text { integration of } \\
\text { value chain } \\
\text { activities }\end{array}$ & $\begin{array}{l}\text { Depending on } \\
\text { sector, } \\
\text { domestic } \\
\text { focus }\end{array}$ & $\begin{array}{l}\text { Depending on } \\
\text { sector, global } \\
\text { sourcing }\end{array}$ & Variable & Global sourcing & $\begin{array}{l}\text { Often } \\
\text { manufacturer } \\
\text { controlled, } \\
\text { production in } \\
\text { home country }\end{array}$ & $\begin{array}{l}\text { Global supply } \\
\text { chain } \\
\text { management }\end{array}$ & $\begin{array}{l}\text { Global } \\
\text { sourcing, } \\
\text { vertical } \\
\text { integration }\end{array}$ & $\begin{array}{l}\text { Global supply chain } \\
\text { management }\end{array}$ \\
\hline
\end{tabular}

Source: Adapted from Atamer et al. (2000). 
of value chain activities was based on whether the financial institution displayed horizontal or vertical integration characteristics. In other words, whether they sought to extend their existing domestic activities in foreign markets or provide a range of activities that were essentially different.

\section{Methodology}

The sample consisted of the 60 largest banks in the world during the period 1999-2003. It was constructed from Banker's (2004) The Top 100 banks and from the annual reports and accounts of the sample banks. The time period was chosen because it occurred well before the introduction of Basel II (Basel, 2004) and the emergence of the recent current credit crunch (Hamalainen, Pop, Hall, \& Howcroft, 2008). As such, it corresponded with a period of relative stability in global financial markets.

In order to identify the different categories of international strategy, content analysis was used to analyse the annual reports and accounts of the sample population. Content analysis, which was popularised by academics, such as Miller (1986) and Miles and Huberman (1984), is a proceduralised approach for capturing complicated qualitative data from diverse sources. Essentially, it involves the identification and extraction of key themes from comprehensive data and is conducive to the identification of categories or main themes and sub-components (see, e.g. Atamer et al. (2000) on international strategies and Perry and Bodkin (2000) on Web page design, etc.).

As there is no consensus or commonly accepted view on the analysis of qualitative data, there has tended to be a proliferation of alternative approaches (Morse, 1994). This can be problematic in so much as it has resulted in a range of different strategies for dealing with data (Cofffey \& Atkinson, 1996; Dey, 1993; Tesch, 1990). Some of these approaches are highly structured or formalised where as others rely on the subjective interpretation of researchers (Saunders, Lewis, \& Thornhill, 2007). The one thing that they all have in common, however, is that they all try to condense highly complicated and context-bound information into a format, which although simplified, is readily understood and informative (Easterby-Smith, Thorpe, \& Lowe, 2003). The paper, accordingly, adopts a data reduction process, which involves the selection, simplification, abstraction and transformation of data to identify and fit predetermined themes and patterns (Ghauri \& Gronhaug, 2005).

Institutions were categorised into the eight international strategies of Atamer et al. (2000) and Bryan et al. (1999), using the five theoretical dimensions shown in Table 1. In this respect, the research followed the approach used by King (2004), Yin (2003), Strauss and Corbin (1998), etc. Specifically, a system of coding was used to identify emergent terminology from the reports. The terminology was then matched with the terms used in the extant literature to describe the theoretical dimensions of the different international strategies.

Another aspect of the research was to try and ascertain the significance or importance of the different international strategies. In this respect, studies of non-financial firms by Markusen (2002), Leknes and Carr (2004), Rugman and Verbeke (2004), etc., have typically used sales volumes, total assets and market capitalisation. However, the final accounts of banks do not follow conventional accounting principles. For example, they do not provide information on sales volumes and regulatory considerations. This means that capital is treated differently compared with other industrial sectors. Accordingly, it was decided to use tier-one capital for banks based on an average figure over the period 1999-2003. 
Tier-one capital is a classification of capital under Basel I, which consists of equity and retained profits and is used to regulate the activities of major banks throughout the world and minimise risk. The rules, which are applied by the Bank for International Settlements (BIS), are complicated but essentially banks must observe a minimum risk asset ratio of 8\% tier-one capital relative to reserve assets, which are weighted according to their underlying risk and liquidity (Hall, 1993). Any increases in tier-one capital must also be matched by an equal increase in tier-two capital, which in broad terms, is represented by subordinated loan stock of different maturities. A major rationale behind these rules, therefore, is to ensure that future growth is financed by equal proportions of profit and equity, and other forms of external borrowing. This approach ostensibly imposes some degree of control on banks because profits are internally generated from successful activities and equity investors arguably provide some form of external control or market discipline on the risk-taking actions of bank management (Hamalainen, Hall, \& Howcroft, 2003).

The allocation of tier-one capital within an individual bank is, therefore, based on senior manager's opinions about which strategies are likely to maximise profitability and increase shareholder value within an acceptable level of risk (Ramachandran et al., 2006; Yang et al., 1992). As such, the amount of tier-one capital associated with a particular strategy implies a high internal (senior management) and external (investment analysts and investors) endorsement of the appropriateness of that strategy for delivering increased profitability at an acceptable level of risk. Tier-one capital is also indicative of the relative size of the sample banks and, therefore, provides some additional insight into the significance of the different international strategies.

\section{Findings}

Figure 1 reveals that just over half of tier-one capital, i.e. \$378,987 million, was accounted for by international (international challengers) rather than global (worldwide players) strategies. Furthermore, 42 banks or $70 \%$ of the sample had adopted international strategies (Table 2). Figure 1 also shows that the opportunistic international challenger with an emphasis on 'home country and a few key countries' was the single most dominant

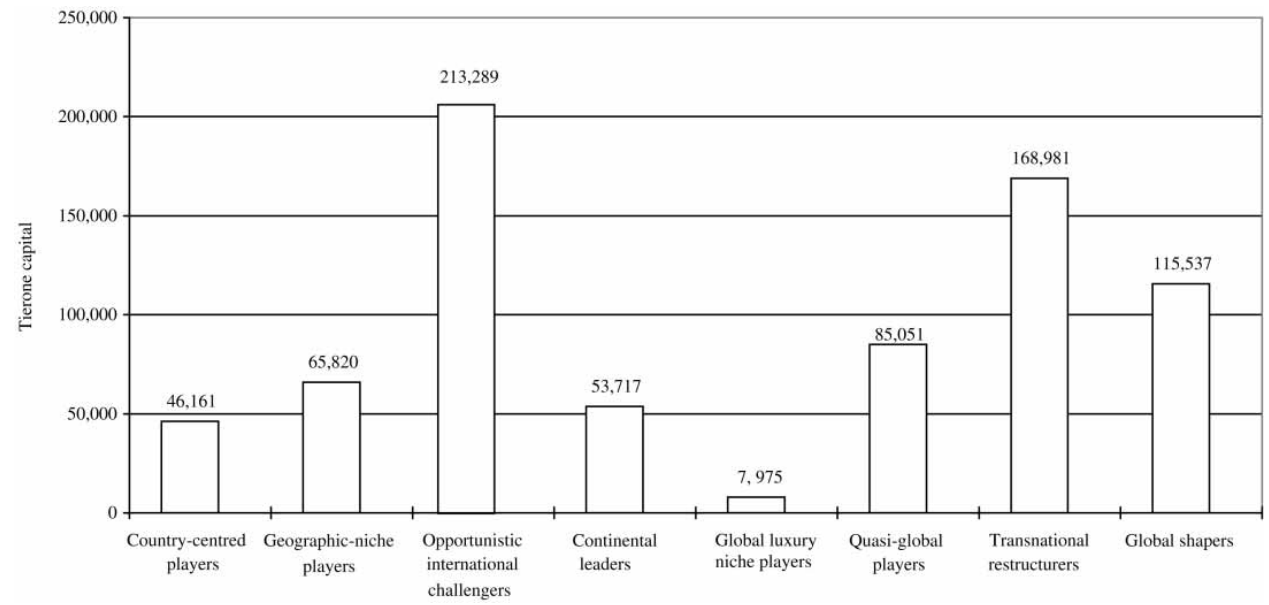

Figure 1. Tier-one capital (\$ millions) verses strategy employed (all banking).

Note: Figures average of 1999-2003 inclusive published data. 
Table 2. Classification of banks by strategy.

\begin{tabular}{|c|c|c|c|c|c|c|c|c|}
\hline & Country-centred players & $\begin{array}{c}\text { Geographic niche } \\
\text { players }\end{array}$ & $\begin{array}{c}\text { Opportunistic } \\
\text { international challengers }\end{array}$ & $\begin{array}{l}\text { Continental } \\
\text { leaders }\end{array}$ & $\begin{array}{c}\text { Global } \\
\text { luxury } \\
\text { niche } \\
\text { players }\end{array}$ & $\begin{array}{l}\text { Quasi-global } \\
\text { players }\end{array}$ & $\begin{array}{l}\text { Transnational } \\
\text { restructurers }\end{array}$ & $\begin{array}{l}\text { Global } \\
\text { shapers }\end{array}$ \\
\hline Bank & $\begin{array}{l}\text { † Abbey National } \\
\text { † Suntrust Bank } \\
\text { † Fifth Third Bankcorp } \\
\text { † Shinkin Central Bank } \\
\text { † Shinsei Bank } \\
\text { † Nykredit Group } \\
\text { † Comerica }\end{array}$ & $\begin{array}{l}\text { † Santander } \\
\text { Central Hispano } \\
+ \text { Banco Bilbao } \\
\text { Viscaya } \\
\text { Argentaria } \\
+ \text { Banca Intesa } \\
\text { † Nordea Bank } \\
\text { † United Overseas } \\
\text { Bank } \\
+ \text { Caja de Ahoroos } \\
\text { y Monte de } \\
\text { Peidad de } \\
\text { Madrid } \\
\text { † Skandinaviska } \\
\text { Enskilda Banken }\end{array}$ & $\begin{array}{l}\text { † Royal Bank of Scotland } \\
\text { † Barclays Bank plc } \\
\text { † Wachovia } \\
\text { † ABN Amro Bank } \\
\text { † Lloyds TSP Group } \\
\text { † NorinchukinBank } \\
\text { † Dexis } \\
\text { † SanPaolo IMI } \\
\text { † Royal Bank of Canada } \\
\text { † Scotia Bank } \\
\text { † LandesBank } \\
\text { † Baden-Wurttemberg } \\
\text { † Danski Bank } \\
\text { † Koomin Bank } \\
\text { † Bank of Montreal } \\
\text { † Caja da Ahorros y Pen. } \\
\text { De Barcelona-la Caixa } \\
\text { † Sumitomo Trust \& } \\
\text { Banking } \\
\text { † HSH Nord Bank } \\
\text { † Allied Irish Banks } \\
\text { † Savenska } \\
\text { Handelsbanken } \\
\text { † ForeningsSparbanken } \\
\text { (Swedbank) } \\
\text { † Erste Bank }\end{array}$ & $\begin{array}{l}\text { † Rabo Bank } \\
+ \text { Societe } \\
\text { Generale } \\
\dagger \text { Commerzbank } \\
+ \text { WestLB } \\
+ \text { Banca Monte } \\
\text { dei Paschi di } \\
\quad \text { Siena } \\
+ \text { Bank of } \\
\text { NewYork } \\
\end{array}$ & $† \mathrm{MBNA}$ & $\begin{array}{l}+ \text { Deutsche } \\
\text { Bank } \\
+ \text { Credit } \\
\text { Swisse } \\
\text { Group } \\
+ \text { National } \\
\text { Australia } \\
\text { Bank } \\
+ \text { Dresdner } \\
\text { Bank } \\
+ \text { Canadian } \\
\text { Imperial } \\
\text { Bank of } \\
\text { Commerce } \\
+ \text { State Street } \\
\text { Corp }\end{array}$ & $\begin{aligned} & \text { Bank of America } \\
& \text { (\& Fleet) } \\
& \text { JP Morgan Chase } \\
& \text { Credit Agricole } \\
& \text { Group } \\
\dagger & \text { HypoVereinsbank } \\
& \text { ING Bank } \\
& \text { Unicredito } \\
& \text { Italiano } \\
& \text { Standard } \\
& \text { Chartered } \\
& \text { Capitalia Gruppo } \\
& \text { Bancario }\end{aligned}$ & $\begin{array}{l}\dagger \text { Citicorp } \\
+ \text { HSBC } \\
\text { Holding } \\
+ \text { UBS } \\
\text { AG }\end{array}$ \\
\hline Total & 7 Banks & 7 Banks & 22 Banks & 6 Banks & 1 Bank & 6 Banks & 8 Banks & 3 Banks \\
\hline
\end{tabular}


strategy, accounting for $\$ 213,289$ million of tier-one capital. This dominance was further underlined by Table 2, which reveals that 22 banks or $36.7 \%$ of the sample adopted this strategy.

Despite this finding, global strategies with 'an all key countries' focus were important too. Accordingly, Figure 1 shows that in aggregate global strategies accounted for $\$ 377,544$ million of tier-one capital. As such, it is only slightly less than that allocated to international strategies. Moreover, the transnational restructurer was the second most dominant strategy in the sample, accounting for $\$ 168,981$ million of tier-one capital. This was followed by global shapers $(\$ 115,537$ million) and quasi-global shapers $(\$ 85,051)$. However, Table 2 reveals that only 18 banks adopted global strategies. Within this broad classification, transnational restructures accounted for eight banks, and quasi-global players and global shapers accounted for eight and three banks, respectively.

The evidence, therefore, indicates that the majority of banks are international rather than truly global organisations. This might be indicative of the basic fact that only very large banks can be truly global organisations. As such, it supports the findings of Focarelli and Pozzolo (2001). However, Kwok and Tadesse (2006) have argued that international strategies are more conducive to risk reduction and increased profitability compared with globalisation.

This latter argument is based on the premise that international challengers, especially country-centred players and geographic niche players, take a more conservative approach to cross-border expansion than worldwide players. For example, they are associated with organisations that are looking to gain market share either within the home country, or a defined geographic region. Similarly, with the exception of continental leaders, they tend to focus on a relatively narrow market or a few market segments and attempt to benefit from economies of scale by providing a homogeneous range of products. Entry mode is variable but for geographic niche players and continental leaders it is mainly organic and cross-border activities are typically financed from profits rather than mergers and acquisitions.

Although international challengers might be more conservative than global players, they are not, however, completely risk-averse. In particular, opportunistic challengers and continental leaders adopt a fairly offensive approach to internationalisation. In this respect, it is interesting to observe how Santander, a geographic niche player (Table 2), has apparently changed its strategy in the aftermath of the recent credit crisis and is now actively acquiring banks that were adversely affected by the crisis. Accordingly, although Santander is still operating within a 'homogeneous territory', it is adopting the more variable and aggressive entry mode more readily associated with opportunistic international challengers. This observation also serves to illustrate that bank strategy is a dynamic process, which can be very responsive to changes in the external environment.

Opportunistic international challengers, such as Lloyds TSB, Royal Bank of Scotland, etc., have generally pursued strategies that are conducive to becoming market leaders in their domestic markets. However, from an international perspective they are not major players. For example, prior to the merger between Lloyds and TSB in 1995, Lloyds had closed down its investment banking business and had rationalised its branch network in Europe and the Far East. Similarly, TSB's strategy was to increase shareholder value by growing the domestic business via a series of well-conceived acquisitions. Accordingly, prior to the credit crunch, Lloyds TSB had a domestic rather than an international focus and only had significant international operations in two countries, namely New Zealand and Brazil. 
The opportunistic international challenger's strategy also reveals that there is no discernable pattern in terms of entry mode, standardisation and integration of value chain activities. This is undoubtedly because although organisations that adopt this strategy are market leaders in their domestic markets, they are still evolving in terms of their cross-border strategies. Accordingly, they take an essentially opportunistic approach to international development and, as a result, there is little or no evidence of a long-term strategic plan.

It could be argued that the ability to react quickly and flexibly to emerging market opportunities is an important part of any long-term plan. Nevertheless, the almost ad hoc approach associated with opportunistic international challengers is a little disconcerting. Accordingly, although the reasons behind the Royal Bank of Scotland's problems, in the immediate aftermath of the recent credit crunch, were complex, it is perhaps not entirely surprising to find that it was classified as an opportunistic international challenger (Table 2).

An examination of the global or worldwide players strategies provides some similarly interesting insights into the cross-border strategies of banks. For example, the least common strategy was global luxury niche players, which consisted of only one organisation, namely MBNA (Table 2). As the world's largest independent credit card issuer, specialising in affinity cards prior to it acquisition by the Banks of America in 2005, it is not surprising to find that its strategy is characterised by a focus on a narrow, relatively highpriced market segment and the provision of a homogeneous product range throughout the world. The nature of MBNA's business is also more conducive to licensing and franchise arrangements rather than mergers and acquisitions.

In contrast, the most significant global strategy both in terms of tier-one capital and the number of banks was transnational restructurers. The emphasis on market share and a diverse range of large business segments is a fair reflection of the activities of very large international banks. For example, the ING Group was formed by the merger of a commercial bank, Nationale-Nederlanden, and an insurance company, NMB Postbank Groep, in 1991. It is a major commercial bank but it is also an important player in asset management and is the world's largest life insurer. Since the merger it has continued to expand its international activities, predominately by mergers and acquisitions, to such an extent that the majority of its business is now located in foreign markets. However, it does not exclusively rely on mergers and acquisitions and has also created start-up ventures in emerging markets, such as China and India.

The transnational restructurer strategy can, however, lead to complex organisational structures and a duplication of activities. Moreover, the emphasis on mergers and acquisitions can also be construed as a fairly aggressive approach to global expansion. Bearing in mind the problems encountered by the Bank of America and JP Morgan Chase in the aftermath of the recent credit crunch, it is interesting to note that over 10 years ago Boot and Thakor (1996) concluded that competitive strategies, which placed an overt emphasis on growth and size could lead to complex corporate governance structures and deflect from innovative thinking.

Global shapers place an emphasis on worldwide coverage but have a relatively narrow focus within a mass market. Accordingly, they provide a fairly comprehensive service within a niche or a segment of a mass market. HSBC, Citicorp and UBS, i.e. organisations that fall within the global shapers classification, are also regarded as being fairly innovative and relatively risk-averse within the sector. To illustrate this point, HSBC Holdings plc, the second largest banking and financial services organisation in the world, is represented in almost 80 countries and territories in Europe, the Far East, the Americas, 
Middle East and Africa. Its global network was formed by a combination of organic growth in Asia and major acquisitions in other regions of the world. The bank also has substantial exposure in developing and emerging markets and has taken a fairly aggressive approach to diversifying its business from commercial banking into wealth management and consumer finance.

In the aftermath of the credit crisis, HSBC has emerged relatively unscathed, but UBS and Citicorp have succumbed to very heavy financial losses. To some extent this might be attributable to their aggressive and innovative approach to business. Accordingly, it is perhaps pertinent to note that Lord Turner (FSA, 2009) concluded that too much innovation within a highly deregulated environment can lead to excessive risk-taking and that this was that a major explanatory reason behind the recent credit crunch.

The fourth and final global strategy was quasi-global players. In many respects, it is similar to global shapers but firms adopting this strategy tend to be relatively more focused both in terms of their geographic scope and portfolio of activities. For example, Deutsche Bank was traditionally involved in commercial and investment banking and insurance. However, deregulation and the commensurate increase in competition have brought about a change in its competitive profile, which is now more concentrated on investment banking and corporate commercial banking. In terms of geographic coverage, until the Hong Kong Bank moved its headquarters to London, Deutsche Bank was the largest commercial bank operating in Europe. Its acquisition of Banker Trust in 1999 also established it as a major player in the USA equities markets. However, although it has operations in the Far East and the emergent markets, its presence compared with HSBC and Citicorp is marginal.

\section{Conclusions}

The paper makes a potentially valuable contribution to the extant literature in a number of different ways. For example, to the best of our knowledge, it is the only empirical study to apply the Atamer et al. (2000) and Bryan et al. (1999) methodologies to the internationalisation of banks. In so doing, it provides some interesting insights into how banks develop their cross-border business and what this involves. These are important considerations because technological developments, the deregulation of financial markets and the emergence of global level playing fields have provided both the opportunity and the means for bank management to develop appropriate international strategies. The emergence and growth of the global economy have also increased market pull pressure on banks and introduced an imperative on bank management to provide a comprehensive global service to corporate customers. The recent banking crisis, however, could fundamentally change the future of international banking. To this extent, a more coherent and comprehensive understanding of the process of internationalisation could be critical in helping individual banks adopt appropriate strategies and benchmark themselves against competitors.

These are important considerations because the paper has revealed that in terms of international strategies, the banking sector is not homogeneous. Individual banks adopt alternative strategies, which reflect different organisational forms, different stages of corporate development and specific managerial and cultural considerations, etc. Moreover, although the research method oversimplifies the categorisation of international strategies, the findings do provide some pertinent insights into the diverse range of strategic approaches to internationalisation in terms of geographic and segment scope, entry policy, standardisation and integration of value chain activities. It was also interesting to find that only a small number of large banks were truly global and that the vast majority 
of banks were international, meaning that they tended to focus on a few countries or a geographic region.

This emphasis on international strategies undoubtedly reflects the high investment costs and the additional risks associated with trying to provide broad scope services throughout the world. However, it also implies that most banks are still evolving in terms of their international strategies and adopt a fairly cautious, incremental approach to internationalisation. The extant literature also suggests that banks tend to move into host countries or regions on the basis of favourable regulatory conditions, or having cultural and social affinity with the home country. This raises the rather worrying possibility that international banking might be determined more by cultural and regulatory conditions rather than the market potential of host countries.

The dominance of opportunistic international challengers suggests that most banks are opportunistic in their approach to internationalisation. The dominance of this strategy also meant that it was difficult to discern any real pattern for entry mode and standardisation, etc. This may be reflecting the fact that banks are not symmetric organisations and can, therefore, differ fundamentally in terms of their core activities and competitive strategies. There was also no strong evidence of a horizontal strategy in which banks perform similar activities in both domestic and foreign markets. To some extent, this finding was unexpected because it is regarded as the norm for most multinational firms. Conversely, it could be argued that a vertical strategy is more conducive to the development of new proprietary skills, the spreading of risks and the diversification of business portfolios.

The research findings are, however, essentially preliminary and have a number of limitations. For example, by focusing on the largest banks in the world the sample is to some extent biased because it does not take into account the cross-border activities of smaller institutions. The use of tier-one capital as a proxy for the relative importance of each strategy is similarly far from ideal because it does not take into account the fact that different types of bank activity incur varying degrees of risk and different levels of capital. This is potentially important because banks typically provide a comprehensive range of commercial banking, investment banking and insurance services.

It would also be interesting to ascertain the relationship between the different international strategies and some measures of efficiency or profitability. Likewise, the recent credit crisis will have undoubtedly changed the internationalisation strategies of individual banks. A comparison of the existing data set with some more recent information might, therefore, throw some light on the way in which the process of internationalisation has changed in the recent aftermath of the credit crisis. The next stage of the research will, therefore, increase and update the data set and address these issues.

\section{References}

Alavarez-Gil, M.J., Cardone-Riportella, C., Lado-Couste, N., \& Samartin-Saenz, M. (2003). Financial service firms' entry-mode choice and cultural diversity: Spanish companies in Latin America. International Journal of Bank Marketing, 21(3), 109-121.

Altman, E., Brady, B., Resti, A., \& Sironi, A. (2005). The link between default and recovery rates; implications for credit risk models and procyclicality. Journal of Business, 78, 2203-2228.

Amel, D., Barnes, C., Pannetta, F., \& Salleo, C. (2003, June). Consolidation and efficiency in the financial sector: A review of the international evidence (CEIS Tor Vergata Research Paper Series, $7(20))$.

Anderson, O. (1993). On the internationalisation process of firms: A critical analysis. Journal of International Business Studies, 24(2), 209-231. 
Atamer, T., Calori, R., Gustavsson, P., \& Menguzzato-Boulard, M. (2000). Internationalisation strategies. In R. Calori, T. Atamer, \& P. Nunes (Eds.), The dynamics of international competition - from practice to theory, strategy series (pp. 162-206). London: Sage.

Banker (2004). The top 100 banks. London: Financial Times Business Limited.

Barros, P.P., Berglof, E., Fulghierri, J., Gual, J., Mayer, C., \& Vives, X. (2005). Integration of European banks: The way forward. London: Centre for Economic Policy Research.

Bartlett, C.A., \& Ghoshal, S. (1989). Managing across borders: The transnational solution. Boston, MA: Harvard Business School Press.

Basel (2004). Basel II: International convergence of capital measurement and capital standards: A review framework (Basel Committee Publications, No 107 on banking supervision).

Bauer, J.N. (1994). The emergence of global networks in telecommunications: Transcending national regulation and market constraints. Journal of Economic Issues, 28(2), 391-402.

Beitel, P.P., \& Schiereck, D. (2001, September). Value creation at the ongoing consolidation of the European banking market (Working Paper 05/01). Witten, Germany: Institute for Mergers and Acquisitions, University of Witten/Herdecke.

Berger, A.N., Dai, Q., Ongena, S., \& Smith, D. (2003). To what extent will the banking system become globalised? A study of bank nationality and reach in twenty European countries. Journal of Banking and Finance, 27, 383-415.

Berger, A.N., DeYoung, R., \& Udell, G.F. (2001). Efficiency barriers to the consolidation of the European financial services industry. European Management Journal, 7(1), 117-130. Bikker, J.A., \& Metzemakers, P.A.J. (2005). Bank provisioning behaviour and procyclicality. Journal of International Financial Markets, Institutions and Money, 15, 141-157.

Boot, A.W.A., \& Thakor, A.V. (1996). Banking structure and financial innovation. In A. Saunders \& I. Walter (Eds.), Universal banking: Financial system design reconsidered (pp. 420-430). Chicago, IL: Irwin Professional Publishing.

Bryan, L., Fraser, J., Oppenheim, J., \& Rall, W. (1999). Race for the World strategies to build a great global firm. Boston, MA: Harvard Business School Press.

Buch, C.M., \& De Long, G. (2004). Cross-border bank mergers: What lures the rare animal. Journal of Banking and Finance, 28, 2077-2102.

Buch, C.M., \& Heinrich, R.P. (2002). Financial integration in Europe and banking sector performance. Kiel, Germany: Kiel Institute of World Economics. Mimeograph.

Buch, C.M., \& Lipponer, A. (2007). FDI versus exports: Evidence from German banks. Journal of Banking and Finance, 31(3), 805-826.

Buckley, P.J., \& Casson, M.C. (1976). The future of the multinational enterprise. London: Macmillan.

Caves, R.E. (1982). Multinational enterprise and the market. Cambridge: Cambridge University Press.

Chang, H. (2004). Globalisation, economic development and the role of the state. London: Zed Books Ltd.

Claessens, S., Demirguc-Kunt, A., \& Huizinga, H. (2000). The role of foreign banks in domestic banking systems. In S. Claessens \& M. Jansen (Eds.), The internationalisation of financial

services: Issues and lessons for developing countries. Boston, MA: Kluwer Academic. Clarke,

G., Cull, R., Soledad, M., Peria, M., \& Sanchez, S.M. (2003). Foreign bank entry: Experience, implications for developing economies, and agenda for further research. The World Bank Research Observer, 18(1), 25-59.

Cofffey, A., \& Atkinson, P. (1996). Making sense of qualitative data; complementary research strategies. Thousand Oaks, CA: Sage.

Dages, G.B., Goldberg, L.B., \& Kinney, D. (2000). Foreign and domestic bank participation in emerging markets: Lessons from Mexico and Argentina. Federal Reserve Bank of New York Economic Policy Review, 6(1), 17-36.

Datamonitor (2006). Global banks industry profile (pp. 0199-2013). London: Author.

De Nicolo, G., Bartholomew, P., Zaman, J., \& Zephirin, M. (2004). Bank consolidation, internationalisation and conglomeration: Trends and implications for financial risk (IMF Working Paper No. WP/03/158). Washington, DC: International Monetary Fund.

Denrell, J., Fang, C., \& Winther, S.G. (2003). The economics of strategic opportunity. Strategic Management Journal, 24(10), 977-990.

Dey, I. (1993). Qualitative data analysis. London: Routledge. 
Di Maggio, P.J., \& Powell, W.W. (1983). The iron cage revisited: Institutional isomorphism and collective rationality in organisational fields. American Sociological Review, 48, 147-160.

Doz, Y. (1980). Strategic management in multinational companies. Sloan Management Review, 21(4), 27-46.

Doz, Y. (1996). The evolution of co-operation in strategic alliances: Initial conditions or learning processes? [Special Issue]. Strategic Management Review, 17, 55-83.

Dunning, J.H. (1997). Alliance capitalism and global business. London: Routledge.

Dunning, J.H. (2001). The eclectic (OLI) paradigm of international production: Past present and future. International Journal of the Economics of Business, 8(2), 173-190.

Easterby-Smith, M., Thorpe, R., \& Lowe, A. (2003). Management research: An introduction. London: Sage Publications.

Erramilli, M.K. (1991). The experience factor in foreign market entry behaviour of service firms. Journal of International Business Studies, 22(3), 479-502.

Fayerweather, J. (1969). International business management. New York, NY: McGraw Hill.

Focarelli, D., \& Pozzolo, A.F. (2001). The patterns of cross-border mergers and shareholdings in OECD countries. Journal of Banking and Finance, 25, 2305-2337.

Focarelli, D., \& Pozzolo, A.F. (2005). Where do banks expand abroad? An empirical analysis. The Journal of Business, 78(6), 2435-2464.

Friedman, M. (2007). The social responsibility of business to increase its profits. In W.C. Zimmerli, M. Holzinger, \& K. Richter (Eds.), Corporate ethics and corporate governance (pp. 173-178). Berlin: Springer.

FSA. (2009). The Turner review: A regulatory response to the global banking crisis. London: Financial Services Authority.

Gardener, E.P.M., Howcroft, J., \& Williams, J. (1999). The new retail banking revolution. The Service Industries Journal, 19(2), 83-100.

Ghauri, P.N., \& Gronhaug, K. (2005). Research methods in business studies: A practical guide. Harlow: FT/Prentice Hall.

Goddard, J., Molyneux, P., Wilson, J.O.S., \& Tavakoli, M. (2007). European banking: An overview. Journal of Banking and Finance, 31(7), 1911-1935.

Grosse, R. (2004). The future of global financial services. Oxford: Blackwell.

Grosse, R. (2005). Are the largest financial institutions really global? [Special Issue]. Management International Review, 45, 129-144.

Grosse, R., \& Goldberg, L.G. (1991). Foreign bank activity in the United States: An analysis by country of origin. Journal of Banking and Finance, 15(6), 1092-1112.

Hall, M.J.B. (1993). Handbook of banking regulation and supervision in the United Kingdom. London: Woodhead-Faulkner.

Hamalainen, P., Hall, M., \& Howcroft, B. (2003). Market discipline: A theoretical framework for regulating policy development. In G. Kaufman (Ed.), Market deregulation in banking: Theory and evidence, research in financial services: Private and public policy (pp. 57-97). Oxford: Elsevier.

Hamalainen, P., Pop, A., Hall, M.J.B., \& Howcroft, B. (2008). Did the market signal impending problems at Northern Rock? An analysis of four financial instruments (Discussion Paper Series, No. 8). Department of Economics, Loughborough University.

Hannan, M.T., \& Freeman, J.H. (1984). Structural inertia and organisational change. American Sociological Review, 49, 149-164.

ul-Haq, R., \& Howcroft, J.B. (2007). An examination of strategic alliances and the origins of international banking in Europe. International Journal of Service Industry Management, 18(2), 120-139.

Hauswald, R., \& Marquez, R. (2006). Competition and strategic information acquisition in credit markets. Review of Financial Studies, 19(3), 967-1000.

Helpman, E., Melitz, M.J., \& Yeaple, S.R. (2004). Export versus FDI. American Economic Review, 94, 300-316.

Johanson, J., \& Vahlne, J.E. (1977). The internationalisation process of the firm - a model of knowledge development and increasing foreign market commitments. Journal of International Business Studies, 8(1), 23-32.

Karimi, J., Yash, Y.P., \& Somers, T.M. (1996). Impact of competitive strategy and information technology maturity on firm's strategic response to globalisation. Journal of Management Information Systems, 12(4), 55-88. 
King, N. (2004). Using templates in thematic analysis of text. In C. Cassell \& G. Symon (Eds.), Essential guide to qualitative methods in organisational research (pp. 256-270). London: Sage.

Kogut, B. (1985a). Designing global strategies: Comparative and competitive value-added chains. Sloan Management Review, Summer, 15-28.

Kogut, B. (1985b). Designing global strategies: Profiting from operational flexibility. Sloan Management Review, Summer, 27-38.

Kwok, C.C.Y., \& Tadesse, S. (2006). National culture and financial systems. Journal of International Business Systems, 37, 227-247.

Lawrence, P.R., \& Lorsch, J.W. (1967). Organisation and environment. Boston, MA: Harvard University Press.

Lawson, T. (1997). Economics \& reality. London: Routledge.

Leknes, H.N., \& Carr, C. (2004). Globalisation, international configurations and strategic implications: The case of retailing. Long Range Planning, 37(1), 29-49.

Lewis, M. (2003). Globalisation and corporate governance. In M. Shanahan \& G. Treuren (Eds.), Globalisation: Australian regional perspectives (pp. 66-94). Adelaide, South Australia: Wakefield Press.

Lumpkin, G.T., \& Dess, G.G. (1996). Classifying the entrepreneurial construct and linking it to performance. Academy of Management Review, 21(1), 135-172.

Luo, Y. (1999). Time-based experience and international expansion: The case of an emerging economy. Journal of Management Studies, 36(4), 504-534.

Markusen, J.R. (2002). Multinational firms and the theory of international trade. Cambridge, MA: MIT Press.

Miles, N.B., \& Huberman, A.M. (1984). Qualitative data analysis: A sourcebook of new methods. London: Sage.

Miller, G.A. (1986). Dictionaries in the mind. Language and Cognitive Processes, 1(1), 171-185.

Morse, J. (1994). Emerging from the data: Cognitive process of analysis in qualitative research. In J. Morse (Ed.), Critical issues in qualitative research methods (pp. 23-41). Thousand Oaks, CA: Sage.

Nellis, J.G., McCaffery, K.M., \& Hutchinson, R.W. (2000). Strategic challenges for the European banking industry in the new millennium. International Journal of Bank Marketing, 18(2), 53-64.

Perry, M., \& Bodkin, C. (2000). Content analysis of 100 companies web sites. Corporate Communications: An International Journal, 6(2), 87-97.

Porter, M.E. (1986). Competition in global industries: A conceptual framework. In M.E. Porter (Ed.), Competition in global industries (pp. 15-60). Boston, MA: Harvard Business School Press.

Ramachandran, J., Mukherji, S., \& Sud, M. (2006). Strategic entrepreneurship in a globalising economy: Evidence from emerging economies. IIMB Management Review, 18(3), 291-302.

Roberts, R., \& Arnander, C. (2001). Take your partners. Houndmills: Palgrave.

Rugman, A.M., \& Verbeke, A. (1998). Multinational enterprises and public policy. Journal of International Business Studies, 29(1), 115-136.

Rugman, A.M., \& Verbeke, A. (2004). A perspective on regional and global strategies of multinational enterprises. Journal of International Business Studies, 35, 3-18.

Sapienza, H.J., Autio, E., Geage, G., \& Zahara, S.A. (2006). A capabilities perspective on the effects of early internationalisation on firm survival and growth. Academy of Management Review, 31(4), 914-933.

Saunders, M., Lewis, P., \& Thornhill, A. (2007). Research methods for business (4th ed.). Harlow: Pearson Education, students.

Slager, A. (2005). Internationalisation of banks: Strategic patterns and performance. Vienna: SUERF, The European Money and Finance Forum.

Strauss, A., \& Corbin, J. (1998). Basics of qualitative research: Techniques and procedures for developing grounded theory (2nd ed.). Thousand Oaks, CA: Sage.

Tesch, R. (1990). Qualitative research: Analysis types and software tools. New York, NY: Flamer.

Tschoegl, A.E. (1983). Size, growth and transnationality among the world's largest banks. Journal of Business, 56(2), 187-201.

Vander Vennet, R. (1996). The effects of mergers and acquisitions on the efficiency and profitability of EC credit institutions. Journal of Banking and Finance, 20, 1531-1558. 
Weiss, L. (2005). Global governance, national strategies: How industrialised states make room to move under the WTO. Review of International Political Economy, 12(5), 723-749.

Westney, E.D. (2006). The regional multinationals: MNEs and 'global' strategic management. Journal of International Business Management, 37(3), 445-449.

Williams, B. (1998). Factors affecting the performance of foreign-owned banks in Australia: A cross-sectional study. Journal of Banking and Finance, 22(2), 197-219.

Yang, Y.S., Leone, R.P., \& Alden, D.L. (1992). A market expansion ability approach to identify potential exporters. Journal of Marketing, 56(1), 84-96.

Yin, R.K. (2003). Case study research: Design and methods (3rd ed.). Thousand Oaks, CA: Sage. 